\title{
Anthropology
}

\author{
Alison C. Joersz \\ Department of Anthropology \\ University of Michigan, Ann Arbor \\ aljoersz@umich.edu
}

\section{Sloganization and the Political Pragmatics of Interdiscursivity: The Social Life of a Haitian Political Critique}

\begin{abstract}
In the weeks leading up to the 2013 Carnival season in Haiti, the release of a Carnival song, "Aloral," sparked controversy because of the song's critical message accusing the Martelly administration of false promises. What began as a pointed political critique (pwen) transformed into a slogan, widely repeated and recontextualized to fit a variety of discursive scenarios. This article examines the entextualization process through which the aloral critique became a slogan ("sloganization"). I explore the social context within which it was released and responded to, the poetic features that favored "detachability," and the political partisanship of its recontextualized usages. By tracing the social life of the aloral critique, I show how it was communally mobilized across time and space through public negotiations of meaning. The aloral case points to the role of political stance-taking and discursive negotiation of meaning as a fundamental aspect of the sloganization process. Beyond the specific case of Haiti, sloganization serves as a useful way to conceptualize the political pragmatics of interdiscursivity, as it points to a "shared" quality of interdiscursive texts while also highlighting the role of differential political productivity. [entextualization, interdiscursivity, political pragmatics, social life of discourse, Haiti]
\end{abstract}

\section{Introduction}

$\mathrm{I}$ n the weeks leading up to the 2013 Carnival season in Haiti, the release of a Carnival song, "Aloral," by the musical group Brothers Posse, sparked controversy because of the song's critical message accusing the Martelly administration of ineffectiveness and false promises. In and of itself, the critical nature of the song was not notable, especially in the context of Haiti's Carnival season, when critiques of government and political officials are the norm rather than the exception. Neither was the critical message of the song particularly new; there had been strong political opposition to Martelly's presidency since he took office in 2011. The cause of the controversy, rather, was the government's response to the song: Brothers Posse was excluded from participating in the government-sponsored Carnival parade.

Following the release of "Aloral" and President Martelly's decision to exclude the band from the official parade, lyrics from the song - most prominently, the word aloral itself, and the pair aloral and ateri-entered the realm of everyday discourse, becoming what Spitulnik refers to as "public words" (1997). The song accused Martelly of

Journal of Linguistic Anthropology, Vol. 25, Issue 3, pp. 303-321, ISSN 1055-1360, EISSN 1548-1395. (C) 2015 by the American Anthropological Association. All rights reserved. DOI: 10.1111/jola.12105. 
being "aloral" (all talk) and called for his administration to "ateri" (bring about concrete results). What began as a pointed political critique (a pwen, in Haitian Creole, or Kreyòl) transformed into a pointed slogan (slogan, in Kreyòl) that was widely repeated and recontextualized to fit a variety of different discursive scenarios.

In tracing the "social life" of the aloral critique (Agha 2005; Spitulnik 1997), I attend to the "interdiscursive webs" that connect past and future speech events (Wirtz 2011) and to the processes of entextualization and circulation through which the text created "felt continuities across speech events" (Agha 2005:2; see also Silverstein 2005). Such links indicate a degree of communicative competence assumed to be shared by participants as a condition of "successful" indexicality (Spitulnik 1997). Cultural transmission and change, as well as communication itself, depend on these interdiscursive links for successful social interaction (Spitulnik 1997; Urban 1991). ${ }^{1}$ This analytical frame necessarily includes utterances and speech events beyond the original performance or text (Bauman and Briggs 1990) and thus helps us to understand the social and political productivity of specific incidents of recontextualization.

My analysis focuses on the process through which aloral was transformed from a performed political critique (chante pwen) into a socially circulated slogan, or public word (Spitulnik 1997). Of particular interest in the aloral case is the political partisanship entailed in recontextualizations. In mobilizing the slogan, speakers were able to express complex political sentiments while also participating in defining Martelly's administration as "all talk." In order to mark this political productivity, I use the term "slogan" and refer to the entextualization/recontextualization process as "sloganization." My use of these terms refers both to an emic genre that is metadiscursively employed in Haiti and to a broader analytical concept.

The analysis that follows begins with attention to the Haitian verbal genre of pwen or voye pwen (the act of "sending" a pwen) as a culturally specific speech genre involving critique and/or insult. I outline the cultural context as well as the interactional characteristics of pwen, particularly the role of the target or "owner" of the pwen in constituting its publicly understood meaning. I contrast the discourse genre of pwen with slogan, treating the entextualization process as a point of differentiation and setting the stage for an understanding of aloral as a chante pwen (a pwen sent through song) ${ }^{2}$ within the context of Haitian Carnival celebrations. I then turn to an analysis of the Brothers Posse song. Through a presentation of the sociopolitical context within which the song was released and the poetic form of the song lyrics, I highlight the aspects that favored the detachability of aloral and, to a degree, ateri. I then trace a series of examples derived from observation of formal and informal interactions in Port-au-Prince, including observations of radio commentary programs. These examples highlight the entextualization (sloganization) process that transformed aloral from a pwen to a slogan, a transformation that included a shift from a singular, direct political critique (source to target) to a repeatedly recontextualized indirect reference. The examples demonstrate both the creative adaptations of the slogan and the sloganization process as politically productive. While the slogan's meaning was broadly shared and recognized, recontextualizations continued to index the political nature of the source critique and, consequently, its usage was circumscribed by political partisanship. ${ }^{3}$ That is, mobilization of it was limited to those taking a political stance in opposition to President Martelly. I conclude my discussion by analyzing President Martelly's public response as an important defining moment for the aloral slogan and as one that contributed to its continued circulation.

By tracing the social life of aloral, I point to the ways in which a verbal genre and political social action intersect in the Haitian context. As will be shown, the aloral critique was communally mobilized across time and space and its meaning publicly negotiated and constituted by the sender (Brothers Posse), an audience (through interdiscursive recontextualizations), and the critique's target (President Martelly). This process signals a politically productive competition to control how actors, events, and processes are understood by a larger public. The sloganization of aloral succeeded in organizing a public and its politics with individuals actively 
participating in the (re)configuration of social relations both interpersonally and nationally. Beyond the specific case of Haiti, I propose "sloganization" as a useful way to conceptualize the political pragmatics of interdiscursivity. Whether harnessing preexisting sentiments or creating new ones, sloganization serves as a diffuse process through which words and phrases become a prepackaged means for expressing and disseminating complex political sentiments.

\section{Pwen and Slogan as Politically Engaged Critique}

As a distinct verbal genre in Haiti, ${ }^{4}$ a pwen is a pointed utterance, one that is both simple and elegantly complex at the same time, packing an indexical "punch" through pithy word play. As Kivland (2012:156) states, "[P]wen are symbolic condensations of reality designed to wield persuasive force." Pwen have a distinct social and historical relationship with Haitian Vodou. In the context of Vodou, pwen play an undeniably prominent role. Brown's (1989:74) general description of pwen characteristics in Vodou is useful in making sense of its usage in other contexts:

Pwen refers to an object or a series of words or actions designed to focus the power of a particular lwa [spirit] and thus enable a person to use that power by internalizing it. Pwen can be sung, swallowed, put under the skin, worn around the neck, or performed over a person. Thus, when $\mathrm{Ogou}^{5}$ sings a point song, at the same time that he is sending a pithy communication to his enemies he is also providing his followers with a talisman to use when they are angry.

Pwen, in this sense, are understood as carrying a degree of power, a force practitioners attempt to control and mobilize in productive ways. The power associated with pwen also goes beyond a Vodou-specific context and often takes the form of a critique or insult utilized both within face-to-face interaction as well as via wider means of dissemination, such as through radio media. Indeed, radio-based political commentary programs often include hosts and guests "sending" pwen (voye pwen) against oppositional political figures. ${ }^{6}$ Politicians, in particular, attempt to harness public support for their interpretations through the deployment of pwen. Pwen and political critiques, for the most part, go hand in hand in the Haitian context (Richman 1990).

Within the field of Haitian studies, scholars who address the topic of pwen tend to identify indirectness as one of its prominent characteristics (e.g., Averill 1997; McAlister 2002). ${ }^{7}$ In practice, however, the use of indirect addressivity or indirect performativity is a strategic choice that depends on the context and the perception of possible repercussions. ${ }^{8}$ While there are clear advantages to the use of indirect addressivity or indirect performativity, direct addressivity, or a minimally veiled message, can also be viewed as advantageous or appropriate in particular contexts, as will be seen in the aloral example.

While direction versus indirection remains a context-based choice on the part of the sender, ${ }^{9}$ this choice is not necessarily always a pragmatic or functionally based one. Aesthetic and creative language use, such as wordplay, abstraction, intensification, or exaggeration, also play a significant role in the creation of a pwen and is one of the primary means through which pwen are evaluated by hearers (Richman 1990). Skill at quick-witted banter and joking are socially valued in Haiti. Particularly valued, as noted by Marcyliena Morgan in regard to African American communities, is the maintenance of "a cool social face" based on "the ability to act on symbolic incidents and subtle varieties of cultural practice with eloquence, skill, wit, patience and precise timing" (Morgan 2002:40). Pwen also involve another key feature of verbal genres found in many African and African Diaspora communities: the collaborative process through which a meaning or interpretation is constituted (Lempert 2012:193). According to Morgan (2002:39), "[T]he system of social face found in African American communities requires speakers and audiences to have nearly equal responsibility, knowledge and power in interactions." In the case of Haitian pwen, the target's response confirms for (over)hearers (i.e., the audience) the veracity of a given 
insult or critique. Targets are said to ranmase or "collect" the pwen that was aimed at them, in keeping with the proverb that asserts "mèt pwen ranmase pwen" (the owner of a pwen collects the pwen). The manner in which one "collects" a pwen plays a significant role in fixing or defining its meaning (Richman 1990:118).

Given that the response to a pwen serves a crucial function in orienting and defining the meaning of a pwen, the hearer or target of the pwen must carefully weigh his or her options in responding. The proper response for a directly or indirectly referenced target is to respond in kind, normally with another pwen. As McAlister (2002:168) explains:

Direct refutation of a pwen steps outside the bounds of the communication style and is considered clumsy; conversely, the sender may deny that a given statement was a pwen and therefore make the overhearer seem paranoid. The overhearer may choose to ignore the message, suspending conflict at the moment. The socially prized way to respond to pwen is to return it with another pwen, enlarging the frame of discourse by challenging or embellishing the utterance of the first communicator.

As will be shown in the aloral example below, the "collection" of the pwen (i.e., President Martelly's public response) favored the transformation of aloral from a pwen to a slogan or public word.

\section{Carnival Chante Pwen}

The Carnival season (Kanaval) in Haiti is much anticipated, with a large portion of the population taking part, both directly and indirectly. Celebrations are held over the course of several weeks, leading up to the main Mardi Gras parade, the defile kanaval, historically held in the capital city, Port-au-Prince. ${ }^{10}$ As music and dance are an important aspect of the celebrations, the Carnival season is a period during which a flood of new songs are released, by nationally recognized bands as well as local neighborhood bands (Comhaire-Sylvain 1951; Kivland 2012). This ritual season is also a period during which social tensions concerning class, race, and politics bubble up to the level of explicit discourse (Averill 1994, 1997; Comhaire-Sylvain 1951). In this way, Carnival celebrations in Haiti are deeply political. As Averill notes, "Carnival is the most important crossroads of music and power in Haiti," and the state, or government, is thus "at pains to co-opt, incorporate, regulate and control Carnival's "critique'" (1997:154). ${ }^{11}$

The defile kanaval is primarily sponsored by the government. A "Carnival Committee" is organized by the Ministry of Culture each year to judge musical submissions and select approximately fifteen bands to participate in the parade. Each chosen band is provided an elaborate char, or float, on which to ride and perform. Chante pwen are composed specifically for Carnival celebrations, many of which are direct or indirect critiques of various power-holders, government officials, and politicians. At the national level, musical groups compete for a spot in the official defile. At the local level, street bands circulate song lyrics via word of mouth as they compete for community support and fanatik (devoted fans) within particular neighborhoods or "zones" (Kivland 2012:142). From the "zone" to the national level, "[I]t is in such celebrations [Carnival/Rara] that politicians and other powerholders may find their faults and shortcomings most unabashedly, vulgarly, and mercilessly trumpeted through the country's mountain pathways and city streets" (Smith 2001:55).

Particularly at the national level, Carnival chante pwen most commonly target politicians and political leaders; they have been likened to a "weapon" deployed against stakeholders (Averill 1997; Smith 2001). Richman (1990:115) asserts that "the ability to use song as an interpersonal weapon is a valued skill in Haiti. Where social norms emphasize the avoidance of direct confrontation, voicing an adage, typically under the transparent veil of non-directed, objectified discourse, serves as a vehicle for persuasive maneuvering, venting hostilities and exercising power." And as Averill (1994:219) notes, "Carnival's anti-authoritarian-and even revolutionary-potential 
also motivates the state and elites to intervene to contain and co-opt carnival and its meanings and to transform carnival (and carnival bodies) into a terrain of class and political conflict." Direct critiques thus risk government censorship (being banned from the defile). Even critiques of a more indirect nature risk censorship; however, in censoring a group (e.g., banning the group from the state-sponsored defile), political officials essentially acknowledge themselves as the intended targets and, in doing so, confirm the veracity of the critique in question. Whether they use direct or indirect addressivity, musicians have the potential to put government officials in a bind, challenging them to censor their critiques. Indeed, Averill (1997) provides numerous examples of musical censorship and the role of chante pwen in serving as a catalyst for the removal of particular government figures throughout Haitian history. ${ }^{12}$ The ousting of dictator Jean-Claude ("Baby Doc") Duvalier in 1986 is one particularly striking example: Baby Doc fled the country one week prior to Carnival celebrations that year, a move that is largely understood as not a mere coincidence (Averill 1997:160).

Yet chante pwen are not simply a form of resistance mobilized once a year; as with pwen more generally, musical critiques of this sort are an art form, appreciated for their poetic structure and aesthetic value. Musicians compete for attention and appreciation from the listening public through creative composition that attends to both content (message/critique) and form (poetic structure). As Richman (2005:17) notes, "[A]lthough pwen may be spoken, singing is the more effective weapon for launching pwen, especially in public antiphonal exchange between leader and chorus." Such an exchange between speaker and audience "can help to create an exaggerated impression of unity, participation, and enthusiasm in a crowd" (Haugerud 1995:85-86). Composing a call-and-response chorus, then, adds to the poetic effect and amplifies the message by encouraging dialogicality. ${ }^{13}$ As will be seen in the aloral case, a call-and-response poetic structure also facilitated detachability of the text and the transformation of it into a slogan/public word.

According to Spitulnik, "public words" are words, tropes, or phrases that are wellknown and standardized to the point that "knowledge of them is virtually essential for one to be considered a communicatively competent member of a particular society or subculture." These words are "condensations or extracts from much longer speech events, and when used, they may function metonymically to index the entire frame or meaning of the earlier speech situation" (Spitulnik 1997:166). As an analytical concept, however, "public word" does not call attention to the politically productive nature of aloral as a slogan, that is, to the partisan stance embedded in the text as an important aspect of its interdiscursive usage. While aloral was broadly recognized as interdiscursively linked to the original critique made by Brothers Posse, it is precisely this political index that limited its usage.

Musical critiques are a significant source from which many slogans derive, but they are surely not the sole source. Kivland (2012:156), in her analysis of Haitian street bands, identifies writing catchy slogans as an explicit goal of those bands:

Much enjoyment comes from crafting a witty slogan, and from deciphering, as well as adding to, its polyvalent meaning. A good slogan is so pithy and so charged that it is said to act like a "punch," compelling people to adopt its viewpoint. Yet for it to be successful, it must also be sufficiently figurative, coded, and polyvalent so that its sender can ensure its uptake while denying any specific intent or the impression of commanding. Slogans, in short, are rhetorical acts of concealment and revelation, representing a deliberate yet artful strategy of political persuasion and organization.

While there are clear similarities between the verbal genres of pwen and slogan, it remains useful to distinguish the two. ${ }^{14}$ Echoing McAlister's (2002:168) tacit terminological distinction, I understand pwen as having the potential to become a slogan through repetition (word of mouth, radio broadcasts, etc.). That is, the distinguishing characteristic is the repeatability of a slogan through the entextualization/ recontextualization process. As with the aloral example, a pwen can become a slogan; 
however, not all pwen do. To summarize, I employ the term "slogan" to refer to a pithy word or phrase that is socially circulated, widely recognized, and politically productive.

\section{The Poetics of "Aloral"}

When the Carnival Committee released the list of 15 bands chosen to take part in the official Carnival parade in late January 2013, the Brothers Posse song "Aloral" had already received a fair amount of attention from the press. The song was noted as particularly direct and forceful with its anti-Martelly message, a deliberate shift away from the more indirect, comedic critique launched by the band during the previous year's Carnival. ${ }^{15}$ While Brothers Posse was initially listed as one of the chosen groups for the 2013 parade, according to reporting on the Carnival Committee's decision, they were later taken off the list. This move sparked considerable backlash and controversy. Days later, in a radio interview just prior to the commencement of Carnival celebrations, President Martelly confirmed rumors that it had been his personal decision to take Brothers Posse off the list, declaring that they would not "create the kind of ambiance his government was seeking ... it's a party that's being organized; it's not a protest." ${ }^{16}$ The irony was lost on no one; President Martelly himself was a professional musician (formerly known as "Sweet Micky"): a flamboyant, crude, and critical singer famous for his Carnival chante pwen against past presidents. Given his historic participation in chante pwen, his decision to exclude the band was widely viewed as political censorship.

Despite exclusion from state-sponsored Carnival celebrations that year, "Aloral" circulated widely. It ultimately became the undisputed hit of the 2013 season: it played constantly on the radio and television, and could be heard emanating from various locations on the streets (cars, homes, portable electronic devices, etc.). An instrumental version of the song was even performed by marching bands in the official defile and other parades around the country. The circulatory "success" of the song, however, came about through the transformation of "aloral" from a pwen launched by Brothers Posse to a widely recognized, recontextualized, and repeated slogan. This process was due to a combination of factors, including the poetic structure of the song, the sociopolitical context of its release, and the diffuse process through which the "all talk" accusation came to be defined as an accurate understanding of Martelly's administration. The president himself was an active participant in this process, a point that will be addressed more thoroughly in the final section.

The sloganization process marking the social life of aloral involved "the process of rendering discourse extractable, of making a stretch of linguistic production into a unit—a text- that can be lifted out of its interactional setting" (Bauman and Briggs 1990:73). The poetic structure of the song favored this entextualization process, presenting the key concepts of aloral and ateri in such a way as to promote detachability: both terms came packaged as ready-made texts that captured the essence of the political critique. The song utilized call-and-response to launch accusations of the president's political promises as "aloral," referring to them as simply talk with no concrete results. It also highlighted and placed aloral in opposition to ateri. This discursive opposition mobilized a dominant ideology in Haiti that separates "talk" from the realm of "action" and valorizes "action" above "talk." In their song, Brothers Posse's "all talk" critique reiterated a familiar ideology, but did so using terms that had not been commonly placed in opposition or heard in everyday interactions (namely, aloral and ateri). Aloral, in particular, had previously been viewed as a more "frenchified" term, based on the phrase à l'oral (in speech), as opposed to the more common Kreyòl-identified term, pawòl. ${ }^{17}$ Increased references to aloral documented after the 2013 Carnival season, however, reflect more than a simple terminological shift. While the process effectively resignified aloral to refer to something as "all talk," recontextualizations of it also indexed a particular political stance in relation to the president currently in office. ${ }^{18}$ 
The song is divided into a number of different sections, the first of which is distinctly separated by rhythm and melody. This section serves as an introduction and includes a statement by lead singer Don Kato in which he proclaims that he is telling the truth and predicts that the song may cause some people to become angry: "Mwen vin pou $m$ chante, mwen vini pou $m$ pale, pou di verite, Gen moun ki pral kontan, gen moun ki pral fache ..." (I've come to sing, I've come to speak, to tell the truth, there will be people who are going to be happy, there will be people who are going to be angry ....). The song then launches into the main melody and rhythm, although with lyrics that serve as an introduction to the song's general critique. This secondary introduction illustrates a scenario in which the lead singer confronts the president in his office, calling for the president to "ateri" his promises. ${ }^{19}$ Following a section in which the lead singer ("DK" in Transcript 1, below) lists the "popular zones" (lowincome districts) of Port-au-Prince, the chorus ("Chor" in the transcript) responds with "ATERI." ${ }^{20}$ This call and response continues as DK makes a direct threat as to what will happen if the president does not ateri:

Transcript 1: Brothers Posse's "Aloral"

2

3

4

5

6

7

8

9

10

11

12

13

14

15

16

17

18

19

20

21

22

23
DK:

Bonjou

mwen mesaje a vin pale mwen di w ak w

$P a$ ta ret tan pou fon ti pale misye danm le dirijan

Son jou mwen tap tan

pou di $m$ kot chanjeman

misye le presidan

Poukisa bilan gen gou lambi

nan bouch ou

Epi nan bouch pèp la

se fye l tèlman gen grangou

Pwomes se det

Pèp la pa jwe pou mande

Chor: ATERI

DK: $\quad$ Site soley delma 2

Chor: ATERI [...]

DK: $\quad$ Etidyan, lapolis dyaspora

yo mande

Chor: ATERI

DK: $\quad$ Si w paka ateri

Chor: $\quad F \grave{~ Z E ̀ L ~ F E ̀ ~ Z E ̀ L ~}$

DK: $\quad$ Si w paka ateri

Chor: $\quad F \grave{~ Z E ̀ L ~ F E ̀ ~ Z E ̀ L ~}$
Good day

I messaged to tell you I've come to talk with you

You couldn't stay and wait for a chat

Mr. and Ms. Government Officials

I waited a day

To say where is the change

Mr. President

Why does the report taste good (like conch)

in your mouth

But in the mouths of the people

it's bitter, so much hunger

Promises are debts

The people aren't playing in asking for

RESULTS

Cité Soleil, Delmas 2

RESULTS [...]

Students, the police, the diaspora

they're asking for

RESULTS

If you can't bring about results

AWAY WITH HIM, AWAY WITH HIM

If you can't bring about results

AWAY WITH HIM, AWAY WITH HIM

As can be seen in the excerpts above, the target of the pwen is explicitly stated ("Mr. and Ms. Government Officials," and "Mr. President"). The song draws on Martelly's campaign slogan "Promises are debts," accusing him of not following through on his promises (for a similar case, see Haugerud 1995:99). The critique is also coupled with a relatively direct threat of "away with him" if results are not actualized.

The main sections follow, including the one transcribed below (Transcript 2) in which aloral and ateri are in direct opposition. In it, DK calls out a specific scandalous event, after which the rest of the band (Chor) responds with "ATERI." This series is immediately followed by one in which the lead singer calls out a generalized social or institutional domain in which the president had promised significant change, and the 
band replies with "ALORAL." In this way, Brothers Posse composed a chante pwen aimed at the president that identified the problem as aloral and proclaimed the solution to be ateri:

\section{Transcript 2: Brothers Posse's "Aloral" (continued)}

1 DK: Nan zafe voyaje, piye lajan

2 Chor: ATERI

3 DK: Nan zafe siren, voye manda

4 Chor: ATERI

5 DK: $\quad$ Kale poster, bloke lari

6 Chor: ATERI

7 DK: $\quad$ Nan zafe BBM, revoke moun

8 Chor: ATERI

9 DK: Edikasyon

10 Chor: ALORAL

11 DK: Etadedwa

12 Chor: ALORAL

13 DK: Anvironman

14 Chor: ALORAL

15 DK: Enerji

16 Chor: ALORAL

17 DK: Tidoudou cheri

18 Chor: ALORAL

19 DK: Kreyasyon anplwa

20 Chor: ALORAL
In the case of all the trips (the president made), wasting money

RESULTS

In the case of sirens (on private vehicles), forcing cars out of their way

RESULTS

The president's posters, blocking the road RESULTS

In the case of BBM, firing people by text RESULTS

Education

ALL TALK

Rule of Law

ALL TALK

Environment

ALL TALK

Energy

ALL TALK

Program "Ti manman cheri"

ALL TALK

Job creation

ALL TALK

In this section of the song, the band references a number of well-known political scandals: the many diplomatic trips taken by the president, government officials using sirens on their private vehicles to more effectively move through traffic, the many large posters of the president advertising his accomplishments, and an incident involving the firing of workers by text message. In line 17, "Ti doudou cheri" references the president's social program titled "Ti manman cheri." This program allotted a small amount of money per month to poor mothers with children enrolled in public schools. ${ }^{21}$

With its rhythm and call-and-response structure, the piece beckons an unseen audience to collaborate in "sending" the pwen against the president and his administration. The simplicity of the song's rhythm, message, and poetic structure facilitated the detachment, repetition, and recontextualization of the key terms aloral and ateri.

\section{The Political Frame of "Aloral"}

Even before the critique lodged by Brothers Posse debuted, Don Kato had been politically opposed to Martelly. Many claimed Martelly to be a Duvalierist, a supporter of the father ("Papa Doc") and son ("Baby Doc") dictators who ruled Haiti from 1957 to 1986. On the other end of the political spectrum, Don Kato is known to have had direct involvement in the anti-Duvalierist political party Lavalas, particularly under René Préval (the former prime minister who was elected president in 1996 and again in 2006). ${ }^{22}$ Martelly's opposition to Lavalas was clear in his 2002 Carnival chante pwen critiquing then-president Jean-Bertrand Aristide's alleged corruption regarding foreign-aid donations of rice; the song became the hit of the 2002 Carnival season. 
Given their political differences and Martelly's history of participation in chante pwen, it comes as no surprise that Kato would choose to lodge a strong critique against President Martelly and that he would do so during the Carnival season. Kato was quoted in Le Nouvelliste describing the song's inspiration:

Last year we released "Stayle" to denounce the behavior of President Martelly who, in the opinion of many, boasts at every turn. Unfortunately, the message was understood in a comical way. This is regrettable. Writing the meringue [a musical genre] this year, I tried a participatory approach, and I did a survey on social networks. I asked my contacts to share with me what they have observed this year in the country. The majority of respondents confirmed that the government has made more promises than achievements. He's just all talk [fait tout à l'oral]. The government has not brought about results, and "Aloral" targets these points of weakness. ${ }^{23}$

Despite Kato's references to a "participatory approach," the critique is very direct. The Brothers Posse case points to the political advantage of direct addressivity.

Ultimately, Martelly's political move of blocking Brothers Posse from participating in the defile served as a response to the band's pwen, confirming (for many) the veracity of the accusations. Indeed, news of Martelly's decision to exclude the band spread like wildfire through the media and brought heightened attention to, commentary on, and sympathy for the band. Radio stations that tended to be critical of the government played "Aloral" constantly, far more often than any other song. This repetition of the song, along with considerable attention to the topic on political commentary programs and in day-to-day interactions, helped to further the extent to which people sang along and sympathized with the band. Many pointed to the president's act of banning groups from participating as a sign of his dictatorial tendencies (a critique repeated long after the Carnival season ended). The song's poetic structure and this sociopolitical context both favored the sloganization process, which in turn helped to solidify "Aloral" as the hit of the 2013 Carnival season.

As we have seen, detachability favored aloral's transformation into a slogan as individuals creatively adapted it to fit a variety of social contexts. Some of these were explicitly political in nature, such as the cartoon shown below (Figure 1), ${ }^{24}$ while others were not. These recontextualizations indirectly indexed the original context and target. This indexing was politically productive in aligning speakers in opposition to the president. Although this indexical relationship to the original critique was widely recognized, its usage was constrained by political partisanship, as will be seen below.

\section{The Social Life of Aloral}

During and immediately following the 2013 Carnival season, aloral could be heard in everyday interactions in the form of simple jokes-as-accusations that something was "just talk." My ethnographic research on the activities and discussions at local Haitian development organizations and prominent radio commentary programs also pointed to the circulation and evolving social life of aloral as politically significant. The data presented here come out of participation in these two contexts rather than from systematic observations of a sample population or researcher elicitations. ${ }^{25}$

Use of the aloral slogan was most notable at one research site, an established and respected human-rights organization known for its frequent public denunciations of both the actions and inactions of President Martelly. As a participant in their weekly staff meetings, I observed a steady increase in recontextualizations following the Brothers Posse Carnival controversy. For example, during one weekly meeting, a participant interjected "Aloral!" in response to a comment that another participant made regarding President Martelly's attempts to attract investment to the country through a program advertising Haiti (in English) as "Open for Business." In doing so, the speaker replicated the call-and-response structure of the song. The speaker and a few listeners giggled in response and the conversation continued. While this particu- 


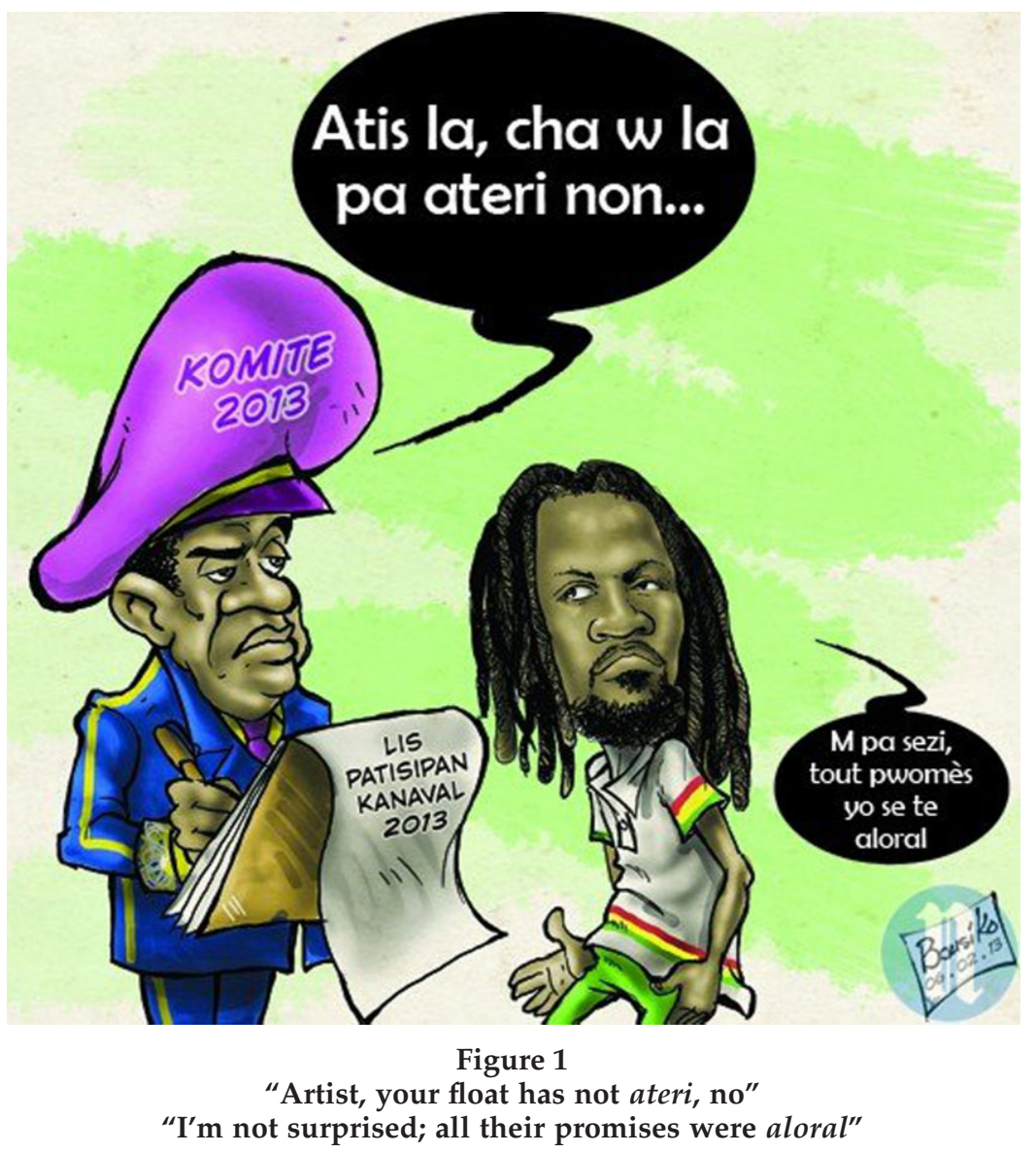

lar occurrence did not elicit extensive feedback, it was clear that fellow participants recognized the interdiscursive and indexical relationship to a source. This scene was repeated at various times and in different conversational contexts within the organization, giving rise to increasing levels of reaction and interaction (giggles, laughs, jokes, rejoinders, etc.).

In other cases, the alignment with the source critique and target was more indirect as aloral was mobilized as a joke in nonpolitical contexts. This was the case at the same organization on a morning when the printer was malfunctioning. The student intern in charge of printing copies of the previous week's meeting notes was unable to do so, which she announced as she approached the meeting table. The organization's director jokingly commented that the notes would be "aloral." His use of aloral in this instance was a play on the French à l'oral, meaning literally that the notes would be read aloud, or orally. If not for the sloganization process, this rejoinder would not have had a humorous effect.

Other instances in which the poetic form of the song was preserved in its recontextualized form came through coupling of aloral with ateri, often but not exclusively in political discussions. For example, as I sat with a friend one day, we discussed his employment with an international NGO (nongovernmental organization) and the organization's objectives. He expressed a degree of skepticism as to the viability of the project, describing it at one point as: "Li aloral kounye a, nou poko rive ateri 1" (It's just talk right now, we haven't yet applied it/produced results). With this 
statement, he recontextualized the song lyrics to the issue being discussed and assessed with me. The source was also indexed by a chuckle and a smile following his statement. Since he was also implicated in the project described, the manner in which he claimed the project had "not yet" produced results distanced him slightly from the source pwen. At the same time, however, his doubts about the viability of the project hinted at semi-alignment with the source critique - that is, with the idea that results would likely be lacking.

The aloral slogan was also recontextualized in more creative ways, straying further from the poetic structure of the source. Many uses, particularly on radio commentary programs, drew on aloral as a noun modifier, with speakers creatively attaching it to something that they wished to point to as not serious, not applied, or not bringing about results. While this was especially the case with radio stations that were explicitly in opposition to the president, it also came up in news reports and debates on less explicitly oppositional stations. It was especially prominent on programs featuring a range of guest participants (civil-society representatives, elected officials, activists, political scholars, etc.), such as the popular Radio Caraibes program "Ranmase," which aired on Saturday mornings. ${ }^{26}$ Recontextualizations of aloral included examples such as "rejim aloral" (government that is just talk) and "kandida aloral" (candidates who are just talk). More often than not, examples such as these were utilized in reference to President Martelly's administration or to candidates who were sympathetic to, or aligned with, him. In these examples, speakers directly aligned themselves in opposition to the president, interdiscursively taking a political stance against his administration. ${ }^{27}$

I also witnessed examples of aloral as noun modifier in contexts less explicitly tied to President Martelly. At another weekly meeting at the previously mentioned human-rights organization, one participant lamented the decline of moral accountability, saying that there seemed to be a tendency in Haiti to have "moral aloral" (morals that are just talk). While the speaker was not directly addressing President Martelly, his use of aloral indexed the source target and aligned his statement with the source critique. ${ }^{28}$

The sloganization of aloral led to a metadiscursive discussion of its meaning on the weekly news program "Hebdomadaire" - specifically, in the episode that aired on April 14, 2013 on the radio station $\mathrm{RCH}$ 2000, a station owned by politician and former Lavalas supporter Arnel Bélizaire. ${ }^{29}$ Following habitual practice on this program, the female host played the role of a naïve information-seeker and her male counterpart took the role of teacher, obliging her requests for more information while performing signs of annoyance and frustration (sighing, talking over her, ignoring her statements or questions, raising his voice, etc.).

The interaction transcribed below was prompted by news of a declaration made by Lavalas political leaders that their party's campaign slogan would be "Aba tout kandida aloral" (Down with all aloral candidates). The first portion shown below (Transcript 3) demonstrates the connection made between the everyday discursive use of aloral and its connection to the source critique. It features the female host $(\mathrm{F})$ questioning the male host $(\mathrm{M})$ about the campaign slogan in question.

\section{Transcript 3: Radio Political Commentary on Aloral}

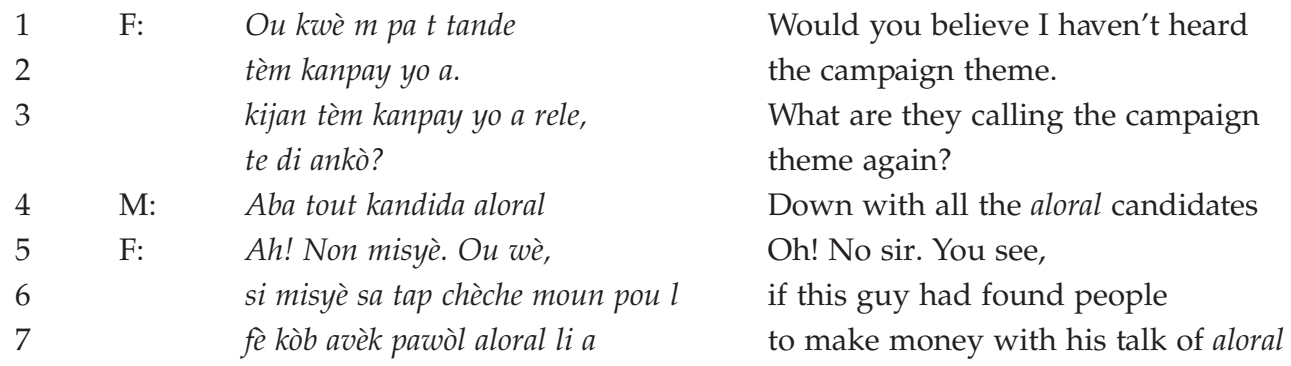


menm si li pa t soti nan kanaval

li ta ka fe kòb

M: $\quad\left[\begin{array}{l}\text { menm se yon ... } \\ \text { yo mande popilasyon an }\end{array}\right.$ pou bay tout moun $\mathrm{ki}$ aloral kanè nan eleksyon even if he didn't take part in Carnival he would be able to make money reven it's a ...

They're asking the population to get rid of all the people who are aloral in the election

Here, F elicits the campaign slogan from $\mathrm{M}$ and reacts to it with exaggerated shock and confusion. She highlights the source critique and author of "Aloral," arguing that Don Kato (and the band more generally) should be making money from the frequent recontextualizations of aloral. In this way, she implies that Brothers Posse are not only responsible for the slogan, but are the owners of it. This discussion is a clear sign of the extent to which the aloral slogan had circulated and the degree to which recontextualizations continued to index the source critique. Following this interaction, $\mathrm{M}$ continued with an analysis of the news (Transcript 4), refusing to entertain further discussion of aloral until later on in the program, when the following exchanges occurred:

\section{Transcript 4: Radio Political Commentary on Aloral (continued)}

\begin{tabular}{|c|c|}
\hline F: & Pierre-Louis, gon lòt bagay ankò \\
\hline & eh ki kandida ki aloral sa yo? \\
\hline & bon koman fe pawòl sa yo? \\
\hline & Ki sa sa vle di? \\
\hline & $\begin{array}{l}\text { Kòmsi tout kandida ka tap pale nan } \\
\text { bouch }\end{array}$ \\
\hline M: & E pa nan bouch ou pale? \\
\hline F: & $\begin{array}{l}\text { Non tout ... kòmsi yo pa di gen anyen, } \\
\text { yo pap fe anyen }\end{array}$ \\
\hline
\end{tabular}

8

9
Pierre-Louis, one other thing

Um what candidates are aloral?

well why are they talking this way?

What does that mean?

It's like all the candidates are able to talk with their mouths

And it's not with your mouth you talk?

No, all ... it's like they're not saying

anything, they're not going to do

anything

I don't know how you make everyone

take up this guy's talk

They're saying people who are aloral

are people who say things like

I'll do that, I'm like that

I'm ... I'll send a lot of kids to school

and then he/she doesn't do anything

In this segment, $\mathrm{F}$ acts confused and pushes to understand the meaning of aloral in its widely circulated form. She begins with a neutral interpretation (from the French à l'oral), which is quickly rejected by $\mathrm{M}$ as inaccurate and ridiculous (line 6). After a brief, generalized, and politically neutral example of how a person who is aloral might act (lines 11-12), M utilizes mock reported speech to draw on the most frequently repeated example (one also cited in the source critique): Martelly's promise to provide free schooling to all children (line 13). By indirectly referencing the target through this reported speech, $M$ draws on his previous statementspresented as politically neutral with an unspecified context-to imply that the freeschooling example is of the same sort. This example of Martelly's campaign promise, and the evaluation of it as aloral, is by no means politically neutral. Citing the example serves to directly align M's on-air persona with the source critique against Martelly. 
As is demonstrated in the examples outlined above, "Aloral" by Brothers Posse had considerable success in making its way into everyday discourse. Speakers recontextualized the song's lyrics in their everyday interactions and, in doing so, they forged interdiscursive ties, signaling its circulation as a slogan, with or without replication of the poetic structure of the song. While the entextualization process of aloral allowed the song to be detached in some ways from its original context, subsequent reentextualizations also retained an interdiscursive relationship to the stance taken in the original critique. The transformation of a pwen into a critical slogan created a concise but indirect way for speakers to voice opposition to Martelly while maintaining a degree of plausible deniability. In Goffman's (1981) terms, speakers took on the role of animator but not author. In the final section, I address the topic of President Martelly's public response to the aloral slogan, a crucial moment in the process of defining the slogan's public meaning and encouraging continued circulation.

\section{Failed Denial: The Branding of an "Aloral" President}

While circulation through the sloganization process was an important factor in defining the slogan's publicly recognized meaning, President Martelly's public responses were also important. In the first, he justified his exclusion of Brothers Posse from the official Carnival parade on the grounds that their song was "inconsistent" with the Carnival theme. ${ }^{30}$ In doing so, he did not follow the socially valued manner in which a target should "gather" (ranmase) a pwen. Rather than responding in kind by means of another pwen, Martelly directly addressed the pwen by taking official action against the band, later stating that the song did not bother him on a personal level.

The general public dismissed Martelly's rationales, claiming that he was "censoring" public expression. The public critique of his response parallels the example given by Richman (1990) in which an American ambassador and Jean-Bertrand Aristide went head-to-head, publicly sending pwen. In a subsequent public address, the ambassador attempted to "explain" his intentions in an effort to correct what he saw as misinterpretations of his use of Kreyòl proverbs. His directness was interpreted by many as "accepting responsibility for the very thing the thrower of pwen strategically avoids" (1990:121): essentially, admitting defeat. Ultimately, Martelly's response promoted the social circulation and sloganization of aloral precisely because his move to exclude the band was read as a sign of the critique's accuracy.

Martelly's second public response came several weeks after Carnival, and was replayed and analyzed by nearly all major news commentators. The newsworthiness and repetition of his statements further demonstrated the degree to which the slogan had come to brand him and his administration as ineffective and "all talk." ${ }^{31}$ This public declaration (Transcript 5), more than simply a second response to the same pwen, was aimed at the Brothers Posse's original critique as well as the aloral slogan in its broadly circulated form. It was widely read as a sign that the slogan had gotten under his skin and that he couldn't let it go. (I have divided his speech into five sections for easy referencing in the analysis that follows. $)^{32}$

\section{Transcript 5: President Martelly's Response to "Aloral"}

1 Nou gen jodi a yon gouvènman ki vle sèvi peyi a, ki vle sèvi popilasyon paske tèt kale pa vin pou pèdi paske ou pa ka kale tèt kale. Tèt kale ap ba nou developman tèt kale. Sak pa kontan, anbake.
We have today a government that wants to serve the country, that wants to serve the population because tèt kale [referring to himself] does not come to lose, because you can't beat me [tèt kale]. Tèt kale will give us development "tèt kale" [all the way]. Those that aren't happy can leave. 
2 Nou pral ateri, nap ateri alekri, nap ateri sou teren an, sou papye, nan tèt ti moun yo, nan vant moun, nan pòch moun.

Paske lè $m$ ba w travay mwen met lajan nan pòch ou.

Lè $m$ ba w edikasyon, mwen met konesans nan tèt ou.

Nap ateri.

3 Se nòmal pou yo di m pa ateri paske kòb leta pa sèvi pou achte bildin miyami ankò.

Se nòmal pou yo di m pa ateri paske leta pa peye nèg pou al fê pwopagann,

pou achte mèsedès ankò.

4 Yo di nou pa ateri.

Nou pa reponn dirèk

paske kòm chèf leta, nou pa ka

rantre nan yon polemik.

Nèg kap pale nou mal.

Moun kap pale nou mal,

se dwa w pou pale nou mal.

Bondye ba w bouch pou pale, pale pale $w$, pale pale $w$, ou mèt pale.

5 Moun kap pale yo se pale yo konn pale, nou menm nou konn chante, nou konn travay.
We are going to get results [ateri], we're going to ateri in writing, we're going to ateri on the ground, on paper, into the heads of children, in people's stomachs, in people's pockets.

Because when I give you work, I'm putting money in your pocket.

When I'm giving you education, I'm putting

knowledge in your head.

We're going to ateri.

It's normal for people to say that I haven't ateri because state money is not being used to buy buildings in Miami anymore.

It's normal for them to say I haven't ateri because the state is not paying people to create propaganda, to continue buying Mercedes Benzes.

They say we aren't going to ateri.

We don't respond directly

because as the leader of the country, we can't enter into a polemic.

Men can talk bad about us.

People can talk bad about us,

it's your right to talk bad.

God gave you a mouth to talk, talk your talk, talk your talk, you can talk.

People who are talking, they're talkers, they know how to talk. Ourselves, we know how to sing, we know how to work.

Martelly's response includes a direct refutation of the aloral pwen in (2), drawing on ateri to claim that his administration would bring about results. In (4), he clumsily denies this directness, presumably as a way to "save face" or control potential interpretations of his discourse as direct and therefore inept. Yet his attempt to deny accusations reads as blundering and defensive in light of the interdiscursive link to the original critique made in (2).

The failure of this response (in competitive pwen terms) is compounded by its attempt to do too much. Martelly also attempts to respond competitively to the original pwen by sending a pwen back at his opponents in (3) and (5). The pwen in (3) is clearly directed at Don Kato, indexing scandals that erupted during Kato's time with the Préval administration, when government funds were said to have been used to buy expensive cars and houses in Miami. In (5), Martelly shifts his aim to a larger public that is repeating and recontextualizing the aloral slogan, marked by references to "people," "men," and "you." On an aesthetic level, his pwen attempts do not meet performance criteria; they are too long-winded and repetitive. Instead of successfully "collecting" the pwen, Martelly's response was widely read as overly defensive.

What is particularly interesting about this response is that, despite utilizing "ateri" repeatedly and thereby directly indexing the source critique, not once did Martelly utter "aloral." This indicates the degree to which uttering the aloral slogan had become tantamount to taking a stance in opposition to the Martelly administration and aligns with a general avoidance of the slogan by government officials sympathetic to the president. While those aligned with Martelly occasionally expressed public complaints about the prevalence of aloral, there was a notable lack of recontextualizations when discussing or defending the president. Thus, aloral was politically productive in that its usage had become a form of stance-taking, with recontextualizations differentially mobilized based on political partisanship. 


\section{Conclusion}

In this analysis, I have traced the social life of aloral as it was transformed via the sloganization process. In its transformation, aloral went from a singular, direct critique to a repeatedly recontextualized indirect reference signaling a political stance in relation to the president. In the process, the aloral slogan interdiscursively maintained its link to the source critique and the political partisanship entailed therein. Despite broad recognition of the slogan's meaning, the partisanship embedded in the aloral slogan resulted in differential use of it.

In an environment where politics are contentious and ambiguities abound, critiques are an important part of day-to-day political engagement through which actors attempt to control how they and others are understood. Through the verbal genre of pwen, Haitian actors vie for public appreciation of their skill in delivering effective critiques and responding to critiques in kind. Despite the use of humor and wordplay, this discursive competition is not merely for play, as it has real political consequences for those involved. The sloganization process through which a critique takes on a more diffuse existence in everyday discourse amplifies those political consequences.

Slogans, whether reflecting preexisting sentiments or creating new ones, serve to organize a public and its politics. However temporary a slogan's social life may be, the sloganization process represents a means through which both unity and political divisions are created and/or maintained. ${ }^{33}$ Sifting through the layers of ambiguity that exist in day-to-day politics, slogans provide clarity and simplified interpretations of actors, events, and processes. This is not to deny the existence of contestation; in fact, contestation plays a key role in the process. The indexical and interdiscursive relationships created through the sloganization process are "recognized and ratified by a collective based on some metacommunity awareness" (Jackson 2013:152). In some instances, a slogan's usage creates interdiscursive moments through which a sense of communitas emerges, signaling a shared bond of political partisanship. In other instances, speakers use it as a political weapon against opponents or as a means to highlight political differences. In this way, sloganization is a process through which words or phrases become a prepackaged means for expressing complex political sentiments.

For a historically marginalized population, the sloganization process also provides a means for a larger public to engage actively in political matters. ${ }^{34}$ Rather than simply being a descriptive repetition of politics "as they are," recontextualizations of critical slogans such as aloral are politically productive in that they actively (re)configure social relations, both interpersonally and nationally. Political critiques, then, have the power to define issues and "create spaces of action that position people with respect to them" (Silverstein 2005:1).

Ultimately, the political productivity embedded in the sloganization process directly contradicts the talk-versus-action ideology entailed in the aloral/ateri critique. In mobilizing the aloral slogan, individuals did not simply repeat and unreflexively "buy into" an understanding of Martelly's administration as ineffective; they actively took a stance and aligned themselves politically with one particular interpretation of the president, thereby participating in defining understandings of him as "all talk." To be sure, the critique of Martelly as ineffective was not initiated by the Brothers Posse song. Interpretations of this sort had circulated nearly from the moment Martelly took office in 2011. What the Brothers Posse song offered, rather, was a pithy version of this critique, readily recontextualized and repeated, and carrying significant indexical and interdiscursive weight in the process. The scattered moments within which the slogan was recontextualized were not only politically productive on an individual level (signaling a political stance) but also became, collectively, an effort to "reorder" the social and political environment "around the fact of their occurrence" (Silverstein 2005:4). While it remains unclear whether the aloral slogan will continue to be a significant indicator of political partisanship in the 
future, what is clear is that the sloganization of aloral branded Martelly's administration as ineffective.

\section{Notes}

Acknowledgments. My sincere gratitude goes to those friends and interlocutors in Haiti who went out of their way to assist me, including Frantz Duval (of Le Nouvelliste), Jerry Bousiquot, Don Kato, and the rest of the Brothers Posse crew. I would also like to thank Michael Lempert, Kristina Wirtz, Stuart Kirsch, Webb Keane, the JLA editors and reviewers, and participants at the 2013 Michicagoan conference for their support, encouragement, and feedback.

1. For more on interdiscursivity, see the Journal of Linguistic Anthropology special issue on the topic (2005, Volume 15, Issue 1). Interdiscursivity is also often referred to as "intertextuality." I follow Bauman's (2005) preference in reserving "intertextuality" for scenarios explicitly focused on written texts.

2. Also referenced in the literature as chan pwen.

3. This analysis is in contrast to that of Squires's (2014), which demonstrates how the process of indexical bleaching, or the loss of an indexical source, facilitates broader diffusion of a text.

4. I draw on Morgan 's definition here, utilizing "verbal genre" to refer to "speakers' use of culturally significant varieties and styles that mediate, constitute and construct contexts" (2002:45).

5. Ogou is a lwa associated with fire, commonly recognized as having a fiery nature.

6. Radio broadcasts are an important means through which information is disseminated. Because it can also be site through which news is created, many listeners are avid followers of their favorite programs (for example, "Ranmase"). In addition to hosting debates between guest participants, many programs also set aside a small amount of time for anyone to call in and discuss issues on the air with the host. Most radio stations are also privately owned, skirting the line between mass and small media. Following Spitulnik (2003:179), radio media should be understood as "a crucial part of civil society and the public sphere, understood most broadly, as the arena where citizens and citizen-based associations discuss state authority, political accountability, and representation."

7. Many Haitian scholars note similarities between pwen and discursive genres found in other African or African Diaspora contexts (e.g., Averill 1997; Kivland 2012; McAlister 2002; Richman 2005). Haitian pwen are noted as resembling African American "signifying" and "sounding" (Gates 1988; Labov 1972; Mitchell-Kernan 1972; Morgan 1996, 2002), Barbadian "dropping remarks" (Fischer 1976), and "throwing" or "dropping words" in Jamaica and Trinidad (Yelvington 1996). To these examples cited by others, I would add that "wording" in Nigerian Pidgin (Faraclas et al. 2005) and the ritual insults of Wolof xaxaar (Irvine 1993) also have a number of characteristics in common with Haitian pwen.

8. My analysis here is similar to that of Morgan's (2002:55) analysis of African American discourse in that she views indirectness as the norm but one within which "the uses of directed and direct discourse styles are viewed as choices."

9. For a detailed analysis of indirection, see Lempert. See also Haugerud (1995) and Brenneis (1987) as examples of indirectness in practice.

10. Since becoming president in 2011, however, President Martelly has chosen a different city each year to host the defile. This change has not been without public (and political) outcry as the defile includes considerable private and public funding.

11. Another similar (but distinct) season in Haiti is Rara. Rara takes place during Easter and includes a week-long celebration involving street bands (with drummers, horns, and dancers) parading in the streets both day and night, marking the end of Lent.

12. In many ways, political critique through song (especially during Carnival season) is more the norm than the exception, with the state having little control over the dissemination of critiques through radio broadcasts. This was not always the case, however, as various stakeholders throughout Haitian history have attempted to silence and otherwise control radio media. While it would be naïve to say that this threat does not still exist, violence against radio stations and journalists during the period of my research was much less common than it had been in the past.

13. A similar case can be found in the Cuban context in which repetition and call-andresponse are regularly utilized to call down orichas (Wirtz, personal communication).

14. Others, such as Kivland, often use the terms interchangeably. 
15. Haiti's daily newspaper, Le Nouvelliste, printed the song's lyrics in its January 23, 2013 issue, followed by an article on Brothers Posse (featuring an interview with lead singer Don Kato) on January 28, 2013. Brothers Posse is generally considered a mereng (méringue) group. Mereng features songs with a syncopated five-beat pattern. This style of music is an important part of Carnival.

16. Jacqueline Charles, "Haitian Bands Say Michel Martelly is Censoring Carnival Songs," Miami Herald. February 8, 2013.

17. Similar to the French term parole, in its simplest form, pawòl means "talk." To "bay pawòl" refers to someone who's just talking or saying what they think the other person needs/wants them to say. One example of "bay pawòl" is to make false promises.

18. Resignification via sloganization is a fairly common process in Haiti. One Haitian scholar referred to this process as "poaching of meanings" (McAlister 2002:169) when discussing the creative and coded use of language during periods of extreme political repression. As one Haitian friend pointed out to me, in discussing the sloganization of aloral, there are many idiomatic phrases or references that remain in use today despite decontextualization from a source. His example was "gran manjè" (big eater) a class critique lodged in a forgotten chante pwen.

19. The music video enacts this scenario and is also the version submitted to the Carnival Committee in competing for participation in the official parade. It is available for viewing via www.youtube.com.

20. Capitalized words or phrases indicate multiple people singing in unison.

21. The amount given was approximately $500 \mathrm{HTG}$ (about US\$11.63 in 2013) a month per child. The program was widely criticized for many reasons and appears to have been a failure given that $85 \%$ of schools in Haiti are private and thus the majority of those living in poor neighborhoods had little chance of obtaining this assistance.

22. In the August 2015 elections, Don Kato ran as a candidate for Senate representing the Western Department (including Port-au-Prince). He ran under the banner of Préval's former party, VERITE.

23. The original text is from the January 28, 2013 edition of Le Nouvelliste, published in French. I have translated it here. As is usually the case with news reports written in French (as most are), it is difficult to know for sure whether the quotations are what the interviewee said or are a translated (into French) version.

24. Cartoon by artist Jerry Boursiquot (Bousiko) that appeared on the cover of Le Nouvelliste, February 6, 2013.

25. For this reason, the analysis necessarily remains incomplete. Because I did not attend to uses of aloral prior to the period in question, I cannot definitively say that it did not have a social life even before the emergence of the Brothers Posse critique. I do believe, however, that the manner of recontextualizations, reactions to them, and the metadiscursive analyses of aloral's post-Carnival usage point to a significant shift in usage even if it did have a pre-Carnival existence. In addition, my discussions about this project with local Haitians July-August 2014, signaled to me that the shift in aloral usage was indeed significant.

26. "Ranmase" is known in particular for bringing oppositional political figures together to debate. To be sure, there is no single oppositional movement in the country thus even the "opposition" has in-fighting that often takes place on the air (with public denunciations being a favored political strategy)

27. The recontextualization style of aloral is in some respects similar to, but in others different from, the phenomenon described by Richman (1990) as non pwen (pwen name). While it seems plausible that aloral could have become a pwen name for President Martelly, instead it became a slogan used primarily as a descriptive modifier. Other pwen names were used to reference Martelly, including "Kale Tèt," a creative reversal of the president's self-given nickname, Tèt Kale. This was a deliberate play on the dual meanings "bald head" (Martelly is bald) and "all the way," used to describe his administration. Those referring to him as Kale Tèt (meaning "to abuse or plunder") were implying that the president was destroying the country. This represents an example of what Haugerud (2013:190-191) describes as "political culture-jamming," in that humor and creative wordplay attempts disrupt the branding messages of politicians by "exposing contradictory meanings."

28. The discussion was in regards to the creation of an electoral council to oversee pending elections. This political "crisis" went on for months as politicians bickered over member appointments. While President Martelly was not directly implicated, he was indeed a key player in the process. 
29. The fact of his ownership of the radio station was publicly known but not advertised explicitly in the station's content.

30. Ann Pote Kole: Yon Ayisyen, Yon Pye Bwa (Let's Bring Them Together: One Haitian, One Tree).

31. On the topic of branding, see Lempert and Silverstein (2012).

32. Transcribed from Radio Kiskeya's commentary program "Interêt Publique" of March 2,

2013. The same speech was aired on a number of different radio stations.

33. Here I follow Jackson $(2013)$ and Haugerud $(1995,2013)$ in their attention to the creation and maintenance of political unity and divisions through discursive means.

34. This cultural process has led many Haitian scholars to interpret music and pwen as a means of "power" for a largely disempowered population (especially in economic terms). See Averill (1997), McAlister (2002), and Smith (2001, 2004) for particularly prominent examples of this scholarly interpretation.

\section{References}

Agha, Asif

2005 Semiosis across Encounters. Journal of Linguistic Anthropology 15(1):1-5.

Averill, Gage

1994 Anraje to Angaje: Carnival Politics and Music in Haiti. Ethnomusicology 38(2):217-247.

1997 A Day for the Hunter, a Day for the Prey: Popular Music and Power in Haiti. Chicago: University of Chicago Press.

Bauman, Richard

2005 Commentary: Indirect Indexicality, Identity, Performance: Dialogic Observations. Journal of Linguistic Anthropology 15(1):145-50.

Bauman, Richard, and Charles Briggs

1990 Poetics and Performance as Critical Perspectives on Language and Social Life. Annual Review of Anthropology 19:59-88.

Brenneis, Donald

1987 Talk and Transformation. Man (N.S.) 22:499-510.

Brown, Karen McCarthy

1989 Systematic Remembering, Systematic Forgetting: Ougou in Haiti. In Africa's Ogun: Old World and New. 2nd edition. S. T. Barnes, ed. Pp. 65-89. Bloomington: Indiana University Press.

2003 Making Wanga: Reality Constructions and the Magical Manipulations of Power. In Transparency and Conspiracy: Ethnographies in the New World Order. H. G. West and T. Sanders, eds. Pp. 233-257. Durham, NC: Duke University Press.

Comhaire-Sylvain, Suzanne

1951 La Chanson Haïtienne. Présense Africaine 12:61-87.

Faraclas, Nicolas, et al.

2005 Ritualized Insults and the African Diaspora: Sounding in African American Vernacular English and Wording in Nigerian Pidgin. In Politeness and Face in Caribbean Creoles. S.

Mühlesien and B. Migge, eds. Pp. 45-72. Amsterdam: John Benjamins.

Fischer, Lawrence

1976 Dropping Remarks and the Barbadian Audience. American Ethnologist 3(2):227-242.

Gates, Henry Louis

1988 The Signifying Monkey: A Theory of Afro-American Literary Criticism. Oxford: Oxford University Press.

Goffman, Erving

1981 Forms of Talk. Philadelphia: University of Pennsylvania Press.

Haugerud, Angelique

1995 The Culture of Politics in Modern Kenya. Cambridge: Cambridge University Press.

2013 No Billionaire Left Behind: Satirical Activism in America. Palo Alto, CA: Stanford University Press.

Irvine, Judith T.

1993 Insult and Responsibility: Verbal Abuse in a Wolof Village. In Responsibility and Evidence in Oral Discourse. J. H. Hill and J. T. Irvine, eds. Pp. 105-134. Cambridge: Cambridge University Press.

Jackson, Jennifer

2013 Political Oratory and Cartooning: An Ethnography of Democratic Processes in Madagascar. Malden, MA: Wiley-Blackwell. 
Kivland, Chelsey

2012 "We make the state": Performance, Politick, and Respect in Urban Haiti. Ph.D. dissertation, Department of Anthropology, University of Chicago.

Labov, William

1972 Language in the Inner City: Studies in the Black English Vernacular. Philadelphia: University of Pennsylvania Press.

Lempert, Michael

2012 Indirectness. In The Handbook of Intercultural Discourse and Communication. C. B.

Paulston, S. F. Kiesling, and E. S. Rangel, eds. Pp. 180-204. Malden, MA: Wiley-Blackwell.

Lempert, Michael, and Michael Silverstein

2012 Creatures of Politics. Bloomington: Indiana University Press.

McAlister, Elizabeth

2002 Rara! Vodou, Power, and Performance in Haiti and Its Diaspora. Berkeley: University of California Press.

Mitchell-Kernan, Claudia

1972 Signifying, Loud-Talking, and Marking. In Rappin' and Stylin' Out: Communication in Urban Black America. T. Kochman, ed. Pp. 315-335. Urbana: University of Illinois Press.

Morgan, Marcyliena

1996 Conversational Signifying: Grammar and Indirectness among African American Women. In Grammar and Interaction. E. Ochs, E. Schegloff, and S. Thompson, eds. Pp. 405-434. Cambridge: Cambridge University Press.

2002 Language, Discourse and Power in African American Culture. Cambridge: Cambridge University Press.

Richman, Karen E.

1990 "With Many Hands, the Burden Isn't Heavy": Creole Proverbs and Political Rhetoric in

Haiti's Presidential Elections. Folklore Forum 23(1/2):115-123.

2005 Migration and Vodou. Gainesville: University Press of Florida.

Silverstein, Michael

2005 Axes of Evals: Token versus Type Interdiscursivity. Journal of Linguistic Anthropology 15:6-22.

2005 The Poetics of Politics: "Theirs" and "Ours." Journal of Anthropological Research 61(1):1-24.

Smith, Jennie M.

2001 When the Hands Are Many: Community Organization and Social Change in Rural Haiti. Ithaca, NY: Cornell University Press.

2004 Singing Back: The Chan Pwen of Haiti. Ethnomusicology 48(1):105-126.

Spitulnik, Debra

1997 The Social Circulation of Media Discourse and the Mediation of Communities. Journal of Linguistic Anthropology 6(2):161-187.

2003 Alternative Small Media and Communicative Spaces. In Media and Democracy in Africa. G. Hydén, M. Leslie, and F. Ogundimu, eds. Pp. 177-205. New Brunswick, NJ: Transaction Publishers.

Squires, Lauren

2014 From TV Personality to Fans and Beyond: Indexical Bleaching and the Diffusion of a Media Innovation. Journal of Linguistic Anthropology 24(1):42-62.

Urban, Greg

1991 A Discourse-Centered Approach to Culture: Native South American Myths and Rituals. Austin: University of Texas Press.

Wirtz, Kristina

2011 Cuban Performances of Blackness as the Timeless Past Still among Us. Journal of Linguistic Anthropology 21(S1):E11-E34.

Yelvington, Kevin A.

1996 Flirting in the Factory. Journal of Royal Anthropological Institute 2(2):313-333. 